\title{
Emerging issues in international education in business contexts
}

\author{
Dr Joanna Crossman \\ School of Management \\ University of South Australia \\ Joanna.Crossman@unisa.edu.au \\ Telephone: +61 883029114 \\ Dr Sarbari Bordia \\ School of Management \\ University of South Australia \\ Sarbari.Bordia@unisa.edu.au \\ Telephone: +61 883027002
}

\begin{abstract}
:
This paper identifies and explores some of the emerging research topics that assist in conceptualising and mapping the field of international education in business. The identified issues include the commercialisation of international education, the role of institutional promises in creating student expectations, student satisfaction, developing international and cultural leadership, cultural identity and adaptation in the new socio-educational context as well as teaching with spirit and about spiritual issues. These diverse agendas illustrate the broad and inter-disciplinary nature of the subject matter particularly where issues surrounding international education in business are approached holistically.
\end{abstract}

\section{Keywords:}

internationalisation, business and management education, leadership, spirituality

\section{Introduction}

The number of international students worldwide continues to increase unabated with 2.5 million recorded in 2004 and an expectation of 7.2 million global enrolments by 2025 (Marklein 2007). Of these, Australia currently boasts the third highest number of international student enrolments, only exceeded by the USA and the UK (Mai 2005). Within Australia, enrolments in business degrees make up the lion's share. Though figures on expanding enrolments suggest potential profits for business schools, the forecast also brings with it the significant responsibility of analysing and meeting the complex and varied needs of international students. In other words, it cannot be assumed that enrolment diversity, of itself, can enrich the educational experience or improve relationships between culturally diverse students (Rothman, Lipset \& Nevitte 2003, p. 8). Inevitably, the consideration of teaching and learning issues for international students represents a large part of the responsibility. In addition, the holistic development of a business professional in an increasingly internationalised workplace includes addressing soft skills and sensitivity to spiritual and ethical values. This paper identifies and discusses some of the emergent research agendas that contribute to and assist in defining international education in business. We focus on the commercialisation of international education, the role of institutional promises in creating student expectations, student satisfaction, developing international and cultural leadership, cultural identity and adaptation in the new socio-educational context, and finally, teaching with spirit and about spiritual issues. These agendas ultimately seek out positive outcomes and experiences for both universities and learners alike and relate fundamentally to human relationships as they are played out in working and learning. 
The relationships between students, academic staff, administrators and management are influenced by the commercial climate surrounding international education. International education in business contexts also needs to be concerned with the issue of students' expectations, institutional promises, and a fulfilling educational experience (e.g., Bordia 2007; Bordia, Wales, Pittam \& Gallois 2006). At the same time, organisations are changing as a result of the forces of internationalisation, globalisation and multiculturalism, now prolifically described and defined (Marginson 2000, p. 24; Prasad, Pringle \& Konrad 2006, p. 1; Tjosvold \& Leung 2003, p. 2).

These shifting circumstances have identified a need for graduates capable of leading in international and culturally diverse workplace contexts; a need with implications for curriculum development in business schools (Crossman 2008). Activities involving online, intercultural and experiential learning can create opportunities for students across the world to work together on shared problems, learning as they do so about what it means to communicate interculturally and critically reflecting upon the experience in meta-cognitive ways (Melkman \& Trotman 2005).

The paper also discusses the development of sensitivities and understandings surrounding spiritual issues within secular higher education. The impetus for exploring this issue lies in the cultural and spiritual diversity of both learning and workplace contexts where guidelines, policies and laws direct organisational practices for which university students need to be prepared (Crossman 2008a; Harris \& Crossman 2005). Spiritual concerns are also part of a broader response to the subjectivities inherent in teaching and learning including the relationships amongst culturally diverse students and teachers.

\section{The implications of commercial aspects of international education}

The marketisation of international education since the 1980s has led to significant shifts in how universities interpret their purpose and activities. International education has increased worldwide and this trend is set to continue (Altbach 2000). By 2007 it generated more than $\$ 10$ billion enrolling 240000 international students, 27\% of whom were located offshore (State of the Sector 2007). Unsurprisingly, revenues are often compared to export industries (it is Australia's fourth largest export) and discussed in terms of the implications for trade and diplomatic relationships (Nelson 2002, p. 41; State of the Sector 2007). Recent media reports cite research that universities are operating more like immigration facilitators than educational institutions (Garnaut 2006) given that Australia, like New Zealand and Canada, now have a deliberate immigration strategy that provides preferential treatment for graduates (Tremblay 2005, p. 197, p. 213).

Concern is evident amongst academics that Australian universities have become increasingly profit-driven (Marginson 2002), acquiring a 'mill' approach to education (Winter, Taylor \& Sarros 2000) that makes it difficult to distinguish between education and business and is arguably damaging to democratic and collegial processes in universities (Bashier, Brand, Dabiri, Fujitsuka \& Tsai 2001; Mok 2003). University staff reputedly reject an increasingly commercial environment that leaves them feeling as though they were mere commodities and without a sense of ownership in hastily constructed programs to meet market needs (Marginson 2002a; McWilliam 2000; Zepke \& Leach 2002, p. 314), and educational discourse where deans are referred to as 'middle managers', courses as 'products' and students as 'customers' (Lentell 2003; Winter, Taylor \& Sarros 2000). It is suggested that lecturers experience a sense of grief for the loss of what McWilliam (2000) describes as an 'ideal'; an iconic ideal perhaps that was apparently loosely associated with the publicly funded liberal university where the pursuit of knowledge was a virtue for its own sake, devoid of institutional instrumental or opportunist motivations (Gillespie 2002; Symes 1999).

The percentage of enrolled international students on campus is far higher in Australia than in the USA or UK (Tremblay 2005, p. 198) and presents a huge challenge that is not shared to the same extent by British and American providers. The challenge extends beyond 
accommodating the learning needs of international students arising out of their own cultural and linguistic experience (Ledwith \& Seymour 2001, p. 1295) to addressing the broader implications of international and local students learning to learn together. How these students interact with one another, the influence of their cultural orientation generally and to learning specifically has deep-rooted implications. What happens in the learning spaces between these students? Are they spaces rich with exchanges and adjusting perspectives or are they spaces of avoidances and silences? Are the environments of Australian business schools characterised, as Ledwith and Seymour (2001, p. 1292) suggest in UK literature, as ethnocentric, leaving international students feeling excluded and disadvantaged regardless of their home culture?

Although cultural diversity in the classroom is potentially one way to encourage internationalisation it is not enough, of itself, to achieve deeper understandings necessary for the development of internationalisation (Rollier \& Nielsen 2004, p. 66). Skilled, informed teaching and careful planning are required to capitalise upon the happy 'gift' that international education has created. If poorly managed, cultural diversity in the classroom, far from bringing valuable cultural experiences to all can in fact result in 'increased tension, frustration and at worst, the reinforcement of prejudices among students' (Ramburuth \& Welch 2005, p. 2). How international students integrate or are welcomed into the community of local learners is a sensitive issue, particularly in times of heightened global political circumstance that appears to contribute to stereotyping and prejudice. It must be addressed however, and researched more extensively.

Some universities may now prove to be playing for high stakes and in a vulnerable position being largely underwritten by international student fees where even a relatively minor downturn of numbers would be enough to seriously damage their viability (Davis 2006). It seems likely that particular universities will continue to specialise and develop their expertise in international and transnational education whilst others may well look to alternatives. Those 'international' universities must work particularly hard at addressing their roles and responsibilities in relation to international education and counter possible perceptions of providing a 'second rate' university experience where teaching and learning quality is sacrificed to higher profit margins. Encouraging culturally diverse students, eager to develop international perspectives for the enrichment of their relationships, their lives and their understandings must take precedence in the focus of universities if the potential for learning ghettos of student subcultures is to take a back seat to deeply forged intercultural friendships and support links (Ledwith \& Seymour 2001, p. 1295). A socially and economically sustainable future, that does not rely on clever marketing to attract international students, would be better linked to 'raising the bar' of expectations in terms of quality, innovation and fostering meaningful learning experiences as well as fostering a genuine collaboration between educational managers and academics (Crossman 2005). For this to happen, the expectations of international students need to be aligned with institutional promises for a positive educational experience.

\section{The role of international students' expectations and psychological contracts in creating a fulfilling educational experience}

International students select educational institutions that they perceive to be able to provide them with a desirable educational, social and personal experience. Some of the issues that these students expect may be dependent on their personal and professional goals. Yet others may stem from the information they gather about the educational institution before enrolment. Fulfilment of these issues will lead to satisfaction with the educational process. Researchers have distinguished between expectations (based on personal needs and goals) and perceptions of institutional promises (generated from promotional material, formal and informal communication, institutional websites, etc.). While all perceptions of promises are expectations, not all expectations are perceptions of promises (Rousseau 1995). Both expectations and perceptions of promises are extensively researched with respect to client and employee satisfaction respectively, albeit from different theoretical perspectives. Both 
perspectives have also impacted upon research in business education in recent years, a summary of which is provided in subsequent paragraphs. This literature has implications for international students in business.

Much of the expectation research in management and general education has followed the SERVQUAL model which is based on the premise that fulfilled expectation leads to satisfaction. This model was first devised by Parasuraman, Zeithaml and Berry (1988) to understand consumer satisfaction with the service industry. Similar to research in consumer psychology, educational research has found that fulfilment of student expectation leads to satisfaction with educational services (e.g., Oldfield \& Baron 2000; Yanhoang \& Kaya 1998). Initial student expectations have been found to be strongly related to course satisfaction (e.g., Appleton-Knapp \& Krentler 2006). Students attribute lack of expected skill or knowledge gain to the course and its instructors (Athiyaman 1997). Students create expectations from previous experiences and learning goals, and the fulfilment of these goals lead to satisfaction (Bordia, Wales \& Pittam 2006). Fulfilment of expectations regarding educational support services such as libraries and administration leads to a satisfying educational experience (Tan \& Kek 2004). However, international students enrolled in business education have not been sufficiently represented in the above mentioned research.

International students, who uproot themselves from familiar social, educational and linguistic surroundings, make many intangible commitments to their educational process and hence to the institution (Bordia 2007). For example, individuals may put their careers on temporary hold to study for an internationally viable business degree. Some may fund their degrees based on savings from weaker currencies. All international students will leave family and friends back in the home country to lead a relatively lonely social life (at least in the initial stages of the educational period). Based on these commitments, their expectations from the educational provider may be different from those of domestic students (Bordia, Wales \& Pittam 2006). International students may feel that their intangible commitments have been disregarded by the educational institution that does not consider their needs. Faced with lack of fulfilment of expectations, international students may choose to leave the institution before degree completion (Bordia, Wales, Pittam \& Gallois 2006). This is neither beneficial to the student nor to the institution. Students will either give up their plans for the chosen degree or enrol in another institution, spending more money and time than originally anticipated. Students may also provide negative word of mouth recommendations about the institutions which may eventually lead to loss of reputation and therefore weaken the number of international students enrolling into the institution (Bordia, Wales, Pittam \& Gallois 2006). Given the importance of expectation fulfilment on learner experience, in this paper, we present international students' expectations as a viable research agenda in business education.

While there are certain similarities between expectations and perceptions of institutional promises, lack of fulfilment of promises has been found to have negative affective impact (such as loss of trust and well-being) whereas lack of fulfilment of expectations have been to diminish satisfaction with the experience (Rousseau 1995). Given the fact that international students would already be feeling some cultural and linguistic displacement in a new country, any further negative affective outcomes from unfulfilled promises may have a devastating impact on their psychological well-being. Perceptions of promises in an employer-employee context have been widely researched in the form of psychological contracts in organisational behaviour (e.g., Robinson \& Morrison 2000; Millward, Purvis \& Cropley 2003). Research on employee psychological contracts has been undertaken on the basic premise that a happy employee, who perceives the organisation to be caring and giving, is more productive and loyal to the organisation (Rousseau 1995).

A psychological contract is a perception of overt or assumed promises individuals expect the other party in a relationship to be obligated to keep (Rousseau 1995). In the case of international students, any explicit promises made to them from informal and formal communication from the institution based on agents and representatives, websites, 
brochures and advertisement would create a psychological contract that would be perceived as institutional obligation. Unlike a written or legal contract, psychological contracts are often not discussed by the parties in the relationship and therefore often perceived differently by each of them. However, the effect of breach of psychological contracts (i.e., lack of fulfilment of promises) can be similar to those of broken legal/written contracts (such as lack of trust, (Deery, Iverson \& Walsh 2006), and negative work attitude and behaviour (Zhao, Wayne, Glibkowski \& Bravo 2007)).

The establishment of multinational corporations in diverse geographic locations has contributed towards the emergence of Western-based education (especially business and technology) into global degrees. The desire of international students to acquire Westernbased degrees has prompted universities from several countries to successfully market themselves around the world. However, with this opportunity of educating international students comes the immense responsibility of being psychological, social and educational carers for these students. Therefore an understanding of international student psychological contracts in business education is essential for institutions to care for these students and provide them with an effective learning experience. As in the case of employees, a happy student, that perceives the educational institution to be caring and giving, will have a positive learning experience and this will generate a positive reputation for the institution. Yet to the best of our knowledge, no research has yet been published on psychological contracts of international students in business education. Business education has also shown a paucity of research on this topic. Only the educational context of research thesis supervision has attracted the concern of researchers working on psychological contracts (Bordia, Hobman, Restubog \& Bordia 2007; Wade-Benzoni, Rousseau \& Li 2006).

A significant consideration for business educational institutions is their reputation. Reputation can be built (or destroyed) by students and alumni via word of mouth recommendations to prospective students and employers (Bordia, Wales, Pittam \& Gallois 2006). Research indicates that employers are more likely to hire students from reputable institutions (Safon 2007). They may also be likely to sponsor executives for further education and professional development to reputable providers of business education. As employee psychological contracts are well recognised amongst leading international organisations, a demonstrated effort by the business educational community to cater towards international student psychological contracts (through research as well as teaching and learning agendas), can further enhance the reputation of business educational institutions. In this paper, we would like to present the research agenda of psychological contracts as a valuable addition to international education in business.

\section{Developing international and cultural leadership}

Managers are expected to show leadership in negotiating, planning, implementing and reviewing the outcomes of projects with colleagues who may not share the same values, beliefs or spiritual orientation (Melkman \& Trotman 2005, p. 4). Such international and intercultural contexts within global and culturally diverse workplaces require leaders who are able to model sensitivity and inform practice in ways that motivate others. Employees from different cultural backgrounds now share social and professional spaces (Mir, Mir \& Wong 2006, p. 169) and communicate either on a face-to-face basis or via the internet. Indeed it is virtually impossible to identify an organisation that does not have some sort of international relationship (Stohl 2001, p. 324, p. 365). Developing strategies and expertise in communicating with others in culturally diverse groups has become a complex matter that needs to be addressed in a timely fashion if universities are able to respond to the increasing recruitment of culturally diverse employees (Gupta \& House 2004). However, serious concern has been raised from within the business community at the apparent lack of managers with a sophisticated understanding of international and cultural issues (Parry \& Proctor-Thompson 2003; Suutari 2002, pp. 218-226). 
Such a state of affairs is problematic given that when issues are approached inappropriately, staff motivation deteriorates, gaining a competitive advantage becomes more difficult and developing critical international alliances less likely (Hoecklin cited in De Anca \& Vázquez 2007, p. 84). Cultural understanding is vital since it influences planning, problem-solving, decision-making, growth, financial performance, innovation and the way time and space affect outcomes and human interaction (Cacioppe 1998, p. 44; Tung \& Thomas 2003, p. 116; De Anca \& Vázquez 2007, p. 6, p. 96; Rossen, Digh, Singer \& Phillips 2000, p. 25).

Large, global organisations recognise that university business schools have an important role in developing leaders with an international perspective (Brabeck-Letmathe 2006) and to some extent they have always been involved in exploring and fostering intercultural understandings (Webb 2005, p. 110). However, there is little agreement on the best way to design programs to develop international and cultural leadership (Rollier \& Nielsen 2004, p. 65 ; Northouse 2007, p. 301). Firstly, curriculum developers are challenged by the crossdisciplinary nature of international and cultural learning involving diverse subjects such as politics, economics and languages for example (Rollier \& Nielsen 2004, p. 65). Secondly, there is the difficulty for universities in designing programs that are sufficiently flexible and dynamic to respond to rapidly changing organisations (Arpan 2003, p. 27; Rollier \& Nielsen 2004 , pp. 71-72). Also, the dearth of research conducted in areas of direct relevance to international and cultural learning (Arpan 2003, p. 26; Suutari 2002, p. 218, p. 230) suggests that curriculum design is arguably less well informed by research than it should be.

Recent research (Crossman 2008) indicates that employers are supportive of rigorous experiential learning referred to as 'the educational way of the future' (Mak, Barker, Logan \& Millman 1999, p. 64). One of the main examples of experiential learning in the context of internationalisation is international exchange (Marginson 2000, p. 27) but authentic experiences can also be gained, for example, through culturally dependent projects involving scenarios where students would need to consider the implications of language, time and space, group decision-making and innovation (Bennis 2003, p. 108; Dilts R \& J cited in De Anca \& Vázquez 2007, p. 95; Prasad, Pringle \& Konrad 2006, p. 3; Rollier \& Nielsen 2004, p. 73).

Holistic approaches designed to develop 'soft skills' for future leaders proficient in international and cultural understandings (Crossman 2008; Boyatzis, Smith \& Blaize 2006, pp. 8-24) will almost certainly include consideration of emotional intelligence and spiritual awareness along with an ability to appreciate how ethnocentricity influences intercultural communication in organisations (Crossman 2008; Rossen, Digh, Singer \& Phillips 2000, p. 25). No doubt attention to holistic approaches will also involve a varied teaching and learning fare of affective, behavioural and cognitive domains (Mak, Barker, Logan \& Millman 1999, p. 64), described elsewhere as attention being paid to knowledge, skills and attitudes (Webb 2005 , p. 64, p. 110). Acknowledging the role of prior learning experiences and cultural identity should also characterise the design of any international and cultural leadership program that may also have a positive effect upon the socio-educational context.

\section{Cultural identity and adaptation in the new socio-educational context}

One of the most significant and yet underrated commitments international students make towards enrolling in a business degree offered in a country where they do not hold citizenship, relates to cultural and linguistic adaptation. Intercultural encounter is a critical feature of international students' social and academic communication. Intercultural encounters require the adaptation of target cultural and linguistic norms and can have a psychological impact by creating anxiety, potential embarrassment, guilt as well as distress amongst participants (Molinsky 2007). Largely, it is the international student who will have to adapt to the target cultural norms, even when the business school is aware of (and indeed celebrates) multicultural values. Individuals who are comfortable with their cultural identities in their home countries find themselves in a culturally vulnerable position when they arrive in their chosen country for educational purposes. Adding to the cultural adaptation can be the 
need to function with a new language. While universities usually make language proficiency a required element for enrolment, the focus is often on academic not socio-cultural aspects of the language usage. Learning to adapt in a new socio-cultural context and often with a language that students do not use for day-to-day issues can cause substantial stress and emotional turmoil amongst international students. Research in the area of second language learning and intercultural communication has posited for decades that culture and its linguistic connotations are inseparable (e.g., Gardner \& Lambert 1972; Rubenfeld, Clément, Lussier, Lebrun \& Auger 2006). Yet little research has been generated on this issue in the realm of international education in business. In this paper we call for exploration of cultural and linguistic identity and adaptation of international students enrolling in business education.

Individuals' willingness to speak in a second or target language has been studied extensively in the migrant population under the theoretical umbrella of ethno-linguistic vitality (Landry \& Bourhis 1997). Individual perceptions of personal cultural strengths or weaknesses, referred to as 'ethno-linguistic vitality', impact upon psychological state in dealing with intercultural communication. Ethno-linguistic vitality has been studied extensively to determine individual willingness to participate in intercultural encounters. Research on ethno-linguistic vitality posits that people with high vitality will find it difficult to adopt norms of the target culture needed for the effective engagement in intercultural communication (Gudykunst, TingToomey \& Chua 1988). While research on ethno-linguistic vitality is prolific in the field of socio-linguistics (e.g., Rubenfeld, Clement, Lussier, Lebrun \& Auger 2006), social psychology (e.g., Montreuil, Bourhis \& Vanbeselaere 2004) and communication (e.g., Lawson \& Sachdev 2004), it has been under researched in the field of international or business education. Moreover, while migrants have participated in studies on ethno-linguistic vitality for decades, international students have been neglected in this body of research owing to their temporary residency status is the target country and culture. However, it would be simplistic to assume that the construct of ethno-linguistic vitality and its impact on interand intra-group communication does not play a vital role in the socio-cultural experience of international students.

Leading from the call for exploration of cultural and linguistic adaption of international students in business education, we posit that research on ethno-linguistic vitality and its effect on intercultural communication within the international student population will make unique contributions to the areas of international education in business specifically as well as intercultural communication in general. Moreover, from a corporate communication perspective, research in this area will have tangible benefits for communicative effectiveness in an increasingly internationalised workplace. Australia, like the USA, Canada and UK, is an example of a highly internationalised workforce. In 2005-06, 97340 skilled migrants entered Australia (Department of Immigration and Citizenship 2007). A prevalence of foreign trained professionals in Australian workplaces is illustrated by the fact that more than 10500 overseas accountants were recruited between 2001 and 2005 (Morganstern 2007).

Knowledge of the effect of ethno-linguistic vitality in intercultural encounters in the workplace will assist in effective intercultural training for communicative effectiveness in organisations thus creating a sustainable multicultural workforce.

\section{Spiritual education in secular culturally diverse business schools}

Spirituality has been identified as an emerging issue worthy of consideration by managers, researchers and teachers (Kernochan, McCormick \& White 2007, p. 61) and is all the more important in culturally diverse learning contexts. Spirituality is best defined, for the purposes of this paper at least, as a non-sectarian, pluralist, less systematic, individually interpreted phenomenon in contrast with religion that is more usually characterised by shared traditions, rituals and sacred texts (Crossman 2003; Farmer 2001; Halford 1999; Rogers \& Dantley 2001). One of the corollaries of cultural diversity in society as it impacts on the workplace and education is a need to be sensitive to and knowledgeable about spiritual beliefs that individuals hold. Indeed, secular business schools would be well advised to incorporate the 
development of spiritual understandings into the curriculum in order to prepare graduates to interpret and implement laws and guidelines relating to spiritual matters and also because spiritual perspectives reportedly contribute to the improvement of net earnings, share prices, morale, staff turnover and reduced stress (Harris \& Crossman 2005; McKew 2002; Thompson 2000, p. 19).

Responding to the place of spiritual issues in learning is embedded in a holistic approach that some view as a backlash to the scientific traditions underpinning many professions (Levitt 2001). Certainly, there is a growing body of evidence that business employees are seeking out spiritual meaning in their work (Harris 2001, p. 45) and questioning its separation from personal experience though some fear that a pluralistic approach could be hijacked by those with a tendency to proselytise their own religions (Mitroff \& Denton 1999, p. 6). Also, spiritual education in secular business schools would arguably contribute to social sustainability as places where culturally diverse students can learn about and with spirituality, developing tolerance, empathy and respect thereby fostering intercultural intimacy, meaning and relevance in human and professional relationships (Crossman 2008a).

\section{Conclusion}

For some decades now, international education has given rise to alternative teaching and learning approaches as well as new kinds of responses to political, economic, cultural, subjective and organisational phenomena as they are played out in the university context. The traditional, somewhat polarised perceptions of business and international education are ripe for review in a process that seeks out new ways for stakeholders to work together, reformulating as they do so, roles, contributions and goals.

In this paper we have attempted to highlight some research agendas worthy of consideration in the area of international education in business. Broadly, we believe research conducted in the areas proposed will significantly impact upon international students' experience (including learning, development and well-being); ability of business educational institutions to effectively manage, train, retain and attract international students and ultimately create a theoretical base for engaging with an increasingly internationalised workforce in many countries including Australia. The research areas delineated in this paper are by no means exhaustive but rather seek to acknowledge those that for us have immediate relevance. It is the beginning of a long and complex process of defining a new field of investigation to which we hope other researchers will continue to contribute. No doubt some raiding of existing disciplines, literatures and research areas in international education, international business and management, for example, will prove necessary. 


\section{References}

Altbach, P 2000, 'The crisis in multinational higher education', Change, vol. 32, no. 6, pp. 28-31.

Appleton-Knapp, SL \& Krentler, KA 2006, 'Measuring student expectations and their effects on satisfaction: the importance of managing student expectations', Journal of Marketing Education, no. 28, pp. 254-264.

Athiyaman, A 1997, 'Linking student satisfaction and service quality perception: the case of university education', European Journal of Marketing, no. 31, pp. 528-540.

Arpan, J 2003, 'Internationalization in the 1970s and 2000', in Leadership in international business education and research, ed A Rugman, Research in Global strategic management series, vol. 8, JAI, Boston.

Bashier, R, Brand, S, Dabiri, A, Fujitsuka, T \& Tsai, C 2001, 'Virtual universities revealed more than just a pretty interface?', Distance Education, vol. 22, no. 1, pp. 212-231.

Bennis, W 2003, On becoming a leader, Basic Books, New York.

Bordia, S 2007, 'Promises to keep: nature of student psychological contracts in TESOL', TESOL in Context, no. 17, pp. 23-29.

Bordia, S, Hobman, EV, Restubog, LD \& Bordia, P 2007, 'Advisor-student relationship in project collaborations: a psychological contract perspective', the 2007 US Academy of Management Conference Proceedings, Philadelphia, USA.

Bordia, S, Wales, L \& Pittam, J 2006, 'The role of student expectations in TESOL: opening a research agenda', TESOL in Context, no. 16, pp. 10-17.

Bordia, S, Wales, L, Pittam, J \& Gallois, C 2006, 'Student expectations of TESOL programs: student and teacher perspectives', Australian Review of Applied Linguistics, no. 29, pp. 4.1-4.18.

Boyatzis, R, Smith, M \& Blaize, N 2006, 'Developing sustainable leaders through coaching and compassion', Academy of Management. Learning \& Education, vol. 5, no. 1, pp. 8-24.

Brabeck-Letmathe, P 2006, 'Quality beyond operational excellence', in Forum, special conference report issue, vol. 8, no. 3, 18th Annual European Association for International Education (EAIE) Conference, Basel.

Cacioppe, R 1998, 'An integrated model and approach for the design of effective leadership development programs', Leadership and Organization Development Journal, vol. 19, no. 1, pp.44-53.

Crossman, J 2008, 'Thinking out there. Employer perspectives on international leadership education in universities', Paper presented at the 7th annual conference of the Pacific Employer Relations Association, Regional, National, Global. Emerging issues in employment relations. Caloundra, Queensland (forthcoming).

Crossman, J 2008a (forthcoming) 'Breaking the silence. Is the time ripe for discussing spirituality in secular professional education in Australia?', in Rethinking work and learning: adult and vocational education for social sustainability, eds P Willis, S McKenzie \& R Harris, Springer, Dordrecht, The Netherlands.

Crossman, J 2005, 'Work and learning. The implications for transnational distance learners', International Education Journal, vol. 6, no. 1, pp. 18-29.

Crossman, J 2003, 'Secular spiritual development in education from international and global perspectives', Oxford Review of Education, vol. 29, no. 4, pp. 503-520.

Davis, G 2006, 'The rising phoenix of competition of competition: what future for Australia's public universities?', Griffith Review, Autumn, pp. 13-31. 
De Anca, C \& Vázquez, A 2007, Managing diversity in the global organization. Creating new business values, trans. A Goodall, Palgrave Macmillan, New York.

Deery, SJ, Iverson, RD \& Walsh, JT 2006, 'Towards a better understanding of psychological contract breach: a study of customer service employees', Journal of Applied Psychology, vol. 91, pp. 166175.

Fact sheet: Overview of skilled migration to Australia 2007, Australian Government, Canberra, viewed 20 April 2007, <http://www.immi.gov.au/media/fact-sheets/24overview skilled.html>.

Farmer, D 2001, 'The biospiritual awakening?', Public Performance and Management Review, vol. 24, no. 4 , pp. $436-439$.

Gardner, R \& Lambert, W 1972, Attitudes and motivation in second language learning, Newbury House, Rowley, Mass.

Garnaut, J 2006, 'Universities being used as immigration factories', Sydney Morning Herald, 30 March.

Gillespie, S 2002, 'Opening minds: the international liberal education movement', World Policy Journal, vol. 18, no. 4, pp. 79-89.

Gudykunst, W, Ting-Toomey, S \& Chua, E 1988, Culture and interpersonal communication, Sage, Newbury Park, CA.

Gupta, V \& House, R 2004, Understanding Leadership in diverse cultures: implications of Project GLOBE for leading international ventures', in Leading in high growth Asia. Managing relationship for teamwork and change, eds D Tjosvold \& L Kwok, World Scientific, New Jersey, pp. 30-54.

Halford, J 1999, 'Longing for the sacred: a conversation with Nel Noddings', Educational Leadership, vol. 56 , no. 4, pp. 28-32.

Harris, H 2001, 'Spirituality at work: some Australian observations', Business \& Professional Ethics Journal, vol. 20, no. 1, pp. 45-58.

Harris, H \& Crossman, J 2005, Getting up-close and personal. The implications of addressing spirituality in university teaching and learning for faculty and professional developers, GIG working paper, November, viewed 14 August 2007, $<$ http://www.unisa.edu.au/hawkeinstitute/gig/projects/trad-virtues.asp>.

Kernochan, R, McCormick, D \& White, J 2007, 'Spirituality and the management teacher. Reflections of three Buddhists on compassion, mindfulness, and selflessness in the classroom', Journal of Management Inquiry, vol. 16, no. 1, pp. 61-75.

Landry, R \& Bourhis, RY 1997, 'Linguistic landscape and ethno-linguistic vitality: an empirical study', Journal of Language and Social Psychology, no. 16, pp. 23-49.

Lawson, S \& Sachdev, I 2004, 'Identity, language use, and attitudes: some Sylheti-Bangladeshi data from London, UK', Journal of Language and Social Psychology, vol. 23, pp. 49-69.

Ledwith, S \& Seymour, D 2001, 'Home and away: preparing students for multicultural management', International Journal of Human Resource Management, vol. 12, no. 8, pp. 1292-1312.

Lentell, $\mathrm{H}$ 2003, 'The importance of the tutor in open and distance learning', in Rethinking learner support in distance education: change and continuity in an international context, eds A Tait \& $\mathrm{R}$ Mills, Routledge Falmer, London.

Levitt, N 2001, 'The sources and dangers of post-modern anti-science: do these intellectual popguns matter?', Free Inquiry, vol. 21, no. 2, pp. 44-48.

Mai, LW 2005, 'A comparative study between UK and US: the student satisfaction in higher education and its influential factors', Journal of Marketing Management, vol. 21, pp. 859-878. 
Mak, A, Barker, M, Logan, G \& Millman, L 1999, 'Benefits of cultural diversity for international and local students: contributions from an experiential social learning program (The Excell Program)', in International Education: The Professional Edge, a set of research papers presented at the $13^{\text {th }}$ Australian International Education Conference, eds D Davis \& A Olsen, Education Australia, Freemantle.

Marklein, MB 2007, 'USA sees first increase in foreign students since 9/11', USA Today, viewed 12 November 2007, <http://www.usatoday.com/news/education/2007-11-11-study-abroad N.htm>.

Marginson, S 2000, 'Rethinking academic work in the global era', Journal of Higher Education Policy and Management, vol. 22, no. 1, pp. 23-35.

Marginson, S 2002, 'The phenomenal rise of international degrees down under', Change, vol. 34, no. 3.

Marginson, S 2002a, 'Education in the global market: lessons from Australia', Academe, vol. 88, no. 3, pp. 37-41.

McKew, M 2002, 'Lunch with Maxine McKew', The Bulletin, 12 February, p. 42.

McWilliam, E 2000, 'The perfect corporate fit: New knowledge for new times', International Journal of Leadership in Education, vol. 3, no. 1, pp. 75-83.

Melkman, A \& Trotman, J 2005, Training international managers. Designing, deploying and delivering effective training for multi-cultural groups, Gower, Aldershot, UK.

Millward Purvis, LJ \& Cropley, M 2003, 'Psychological contracting: processes of contract formation during interviews between nannies and their "employers"', Journal of Occupational and Organizational Psychology, no. 76, pp. 213-241

Mir, R, Mir A \& Wong, D 2006, 'Diversity. The cultural logic of global capital?', in Handbook of workplace diversity, eds A Konrad, P Prasad \& J Pringle, Sage, Thousand Oaks.

Mitroff, I \& Denton, E 1999, A spiritual audit of corporate America. A hard look at spirituality, religion and values in the workplace, Jossey-Bass, San Francisco.

Mok, KH 2003, 'Globalisation and higher education restructuring in Hong Kong, Taiwan and Mainland China', Higher Education Research and Development, vol. 22, no. 2, pp. 117-130.

Molinsky, A 2007, 'Cross-cultural code-switching: the psychological challenges of adapting behaviour in foreign cultural interactions', Academy of Management Review, no. 32, pp. 622-640.

Montreuil, A, Bourhis, R \& Vanbeselaere, N 2004, 'Perceived threat and host community acculturation orientations towards immigrants: comparing Flemings in Belgium and Francophones in Quebec', Canadian Ethnic Studies, no. 36, pp. 113-135.

Morganstern, B 2007, 'Synch1: Australia jobs immigration migration law change', Israel News Agency: Canberra, viewed 20 April 2007, <http://www.israelnewsagency.com/australiaimmigrationmigrationlawsjobssynch1041507.html >.

Nelson, B 2002, Higher Education Report for the 2002 to 2004 Triennium. Canberra: Commonwealth Department of Education, Science and Training.

Northouse, P 2007, Leadership. Theory and practice, 4th edn, Sage, Thousand Oaks.

Oldfield, BM \& Baron, S 2000, 'Student perceptions of service quality in a UK university business and management faculty', Quality Assurance in Education, no. 8, pp. 85-95.

Parasuraman, A, Zeithaml, VA \& Berry, LL 1988, SERVQUAL: A multiple item scale for measuring consumer perceptions of service quality, Journal of Retailing, vol. 64, no. 1, pp. 12-40.

Parry, K \& Proctor-Thompson, S 2003, 'Leader career development. Who should take responsibility?', Asia Pacific Journal of Human Resources, vol. 41, no. 3, pp. 316-337. 
Prasad, P, Pringle, J \& Konrad, A 2006, 'Examining the contours of workplace diversity. Concepts, contexts and challenges', in Handbook of workplace diversity, eds A Konrad, P Prasad \& J Pringle, Sage, Thousand Oaks.

Ramburuth, P \& Welch, C 2005, 'Educating the global manager: cultural diversity and cross-cultural training in international business education', Journal of Teaching in International Business, vol. 16, no. 3/4, pp. 5-27.

Robinson, S \& Morrison, EW 2000, 'The development of psychological contract breach and violations: a longitudinal study', Journal of Organizational Behavior, no. 21, pp. 525-546.

Rogers, J \& Dantley, M 2001, 'Invoking the spiritual in campus life and leadership', Journal of College Student Development, vol. 42, no. 6, pp. 589-603.

Rollier, B \& Nielsen, C 2004, 'Approaches for internationalizing the business school curriculum', in The cutting edge of international management education, eds C Wankel \& R Defillippi, Information Age Publishing, Greenwich, Connecticut.

Rossen, R, Digh, P, Singer, M \& Phillips, C 2000, Global literacies, Simon \& Schuster, New York.

Rothman, S, Lipset, S \& Nevitte, N 2003, 'Does enrolment diversity improve university education?', International Journal of Public Opinion Research, vol. 15, no. 1, pp. 8-26.

Rousseau, DM 1995, Psychological contracts in organizations: understanding written and unwritten agreements, Sage, Newbury Park, CA.

Rubenfeld, S, Clement, R, Lussier, D, Lebrun, M \& Auger, R 2006, 'Second language learning and cultural representations: beyond competency and identity', Language Learning, no. 56, pp. 609631.

Safón, C 2007, 'Factors that influence recruiters' choice of B-schools and their MBA graduates: evidence and implications for B-schools', Academy of Management Learning and Education, no. 6, pp. 217-233.

State of the Sector 2007, National Tertiary Education Union, Policy and Research Unit, NTEU National Office, PO Box 1323, Melbourne.

Stohl, C 2001, 'Globalizing organizational communication', in The new handbook of organizational communication. Accessing theory, research and methods, eds F Jablin \& L Putnam, Sage, Thousand Oaks.

Suutari, V 2002, 'Global leader development: an emerging research agenda', Career Development International, vol. 7, no. 4, pp. 218-233.

Symes, C 1999, 'Working for your future. The rise of the vocational university', The Australian Journal of Education, vol. 43, no. 3, pp. 241-256.

Tan, K \& Kek, S 2004, 'Service quality in higher education using an enhanced SERVQUAL approach', Quality in Higher Education, vol. 10, no. 1, pp. 17-24.

Tjosvold, D \& Leung, K 2003, 'Cross-cultural foundations: traditions for managing in a global world', in Cross-cultural management. Foundations and future, eds D Tjosvold \& L Kwok, Ashgate, Hampshire, England.

Thompson, W 2000, 'Can you train people to be spiritual?', Training and Development, vol. 54, no. 12, pp. 1-19.

Tremblay, K 2005, 'Academic mobility and immigration', Journal of Studies in International Education, vol. 9, no. 3, pp. 196-228.

Tung, R \& Thomas, D 2003, 'Human resource management in a global world: the contingency framework extended' in Cross-cultural management. Foundations and future', eds D Tjosvold \& L Kwok, Ashgate, Hampshire, England. 
Wade-Benzoni, KA, Rousseau, DM \& Li, M 2006, 'Managing relationships across generations of academics: psychological contracts in faculty-doctoral student collaborations', International Journal of Conflict Management, no. 17, pp. 4-33.

Webb, G 2005, 'Internationalisation of curriculum. An institutional approach', in Teaching International Students. Improving learning for all, eds J Carroll \& J Ryan, Routledge, Abingdon, Oxford.

Winter, R, Taylor, T \& Sarros, J 2000, 'Trouble at mill: quality of academic worklife issues with a comprehensive Australian university', Studies in Higher Education, vol. 25, no. 3, pp. 279-294.

Yanhong, R \& Kaya, M 1998, 'A case study for comparing two-service quality measurement approaches in the context of teaching in higher education', Quality in Higher Education, no. 4, pp. 103-113.

Zhao, H, Wayne, SJ, Glibkowski, BC \& Bravo, J 2007, 'The impact of psychological contract breach on work-related outcomes: a meta-analysis', Personnel Psychology, no. 60, pp. 647-680.

Zepke, N \& Leach , L 2002, 'Appropriate pedagogy and technology in a cross-cultural distance education context', Teaching in Higher Education, vol. 7, no. 3, pp. 309-321. 